\title{
Vegetational responses of a mixed-grass prairie site following exclusion of prairie dogs and bison
}

\author{
M. SILVIA CID, JAMES K. DETLING, APRIL D. WHICKER, AND MIGUEL A. BRIZUELA
}

\section{Abstract}

Combined grazing by black-tailed prairie dogs (Cynomys ludovicianus) and bison (Bison bison) produces and maintains a series of changes in the vegetation of prairie dog colonies. However, because their grazing patterns differ in frequency and intensity through time, their individual impacts may be different. The objective of this study was to determine the individual and combined influences of these 2 herbivores in maintaining selected vegetation characteristics of a prairie dog colony in a mixed-grass prairie at Wind Cave National Park, S.D. This was assessed by monitoring plant responses during 2 years following exclusion from grazing by 1 or both species. In spite of their different grazing patterns, prairie dogs and bison had similar and independent (i.e., additive) effects in maintaining plant community structure. For example, total aboveground biomass increased $32-36 \%$ within 2 years of removal of each species, primarily as a result of increases in accumulation of graminoid biomass. Plant species diversity, equitability, and dominance concentration were similar in all treatments both years, although there were slight decreases in relative abundance of forbs and increases in relative abundance of graminoids in the second year after removal of grazers. Mean graminoid leaf nitrogen concentration (May to September) declined slightly but significantly after removal of prairie dogs (1.49 to $1.38 \%$ ) in 1985 , and after bison exclusion (1.64 to $1.50 \%$ ) in 1986. We suggest that rate of vegetation change following removal of grazers depends upon weather conditions, plant species composition, and prior intensity and duration of grazing.

Keywords: prairie dogs, bison, grazing patterns, release from grazing, vegetation response, mixed-grass prairie, nitrogen concentration

Where both are present, black-tailed prairie dogs (Cynomys ludovicianus) and bison (Bison bison) directly and indirectly control numerous structural and functional properties of grasslands (Whicker and Detling 1988a, 1988b). Among the native herbivores, they probably have had some of the greatest impacts on North American grasslands, and there is evidence of positive interactions between them (Krueger 1986). Sedentary, colonial prairie dogs alter the vegetation and produce patches which differ from the surrounding uncolonized grassland. These patches are used preferentially for grazing and resting activities by larger herbivores such as bison, elk (Cervus elaphus), and pronghorn (Antilocapra americana) (King 1955, Coppock et al. 1983b, Wydeven and Dahlgren 1985, Krueger 1986). Bison herds graze a given prairie

\footnotetext{
Cid and Brizuela are professors, Facultad de Ciencias Agrarias, Universidad Nacional de Mar del Plata (7620) Balcarce, Argentina; Detling is senior research scientist, Natural Resource Ecology Laboratory, Colorado State University, Fort Collins, Colorado 80523 and professor, Department of Biology, Coloradn State University; Whicker is research associate, Natural Resource Ecology Laboratory. At the time of this research, Cid and Brizucla were visiting scientists, Natural Resource Ecology Laboratory, and graduate students, Range Science Department.

We are grateful to the staff of Wind Cave National Park, and particularly to Park Biologist Richard Klukas and Superintendent Ernest Ortega, for their cooperation and logistic support. We are indebted to J.E. Ellis, D.M. Swift, and R.G. Woodmansee for many helpful suggestions and to P.L. Chapman and J. Moore for assistance with statistical analysis. This work was supported by Consejo Nacional de Investigaciones Cientificas Técnicas (Argentina) and National Science Foundation (USA) Grant BSR 8406660 .

Manuscript accepted 18 June 1990.
}

dog colony relatively infrequently, but on these occasions they remove large amounts of forage. On the other hand, the grazing pressure of prairie dogs is relatively constant and intense throughout the growing season. The combined impact of these herbivores alters grassland structure in such a way that prairie dog colonies become patches of intensified biological activity compared with the surrounding, lightly grazed mixed-grass prairie (Whicker and Detling 1988a).

Some studies have directly examined the temporal and spatial effects of combined grazing by prairie dogs and large ungulates (bison or cattle) upon grassland vegetation (Koford 1958; O'Meilia et al. 1982; Coppock et al. 1983a,b; Collins and Barber 1985; Knowles 1986). However, the effects of exclusion or elimination of prairie dogs, large ungulates, or both upon plant or ecosystem characteristics has received less attention (Osborn and Allan 1949, Klatt and Hein 1978, Uresk 1985, Krueger 1986). Because prairie dog control, with the objective of improving forage quantity and quality, is an important management policy on rangelands (Hansen and Gold 1977, O'Meilia et al. 1982), studies of this nature are necessary to better define the rate and amount of change in grasslands following their removal.

Previous studies at Wind Cave National Park, South Dakota indicated that combined grazing by prairie dogs, bison, and other herbivores such as pronghorn decreased the proportional contribution of graminoids to peak biomass, increased plant species diversity and graminoid equitability, and increased shoot nitrogen concentration (Coppock et al. 1983a, Krueger 1986, Archer et al. 1987). We hypothesized that release from grazing by prairie dogs, bison (and other native ungulates), or both would reverse these trends. Furthermore, because prairie dog grazing is relatively continuous throughout the year, and ungulate grazing is intermittent, we hypothesized that prairie dog exclusion would have a greater impact on vegetation than ungulate exclusion. In this paper, we report results of a 2-year field experiment conducted to evaluate these hypotheses.

\section{Study Area}

Wind Cave National Park (WCNP) occupies 11,355 ha at the southeastern edge of the Black Hills in western South Dakota. About three-quarters of the Park is northern mixed-grass prairie and the remainder is predominantly ponderosa pine (Pinus ponderosa) forest (Dalsted et al. 1981). In 1985 and 1986, there were 9 active black-tailed prairie dog colonies which covered 5-6\% of the total area of WCNP. Free-ranging populations of approximately 350 bison, 350 elk, and 75 pronghorn inhabited the park.

This research was conducted in Research Reserve prairie dog colony, a colony that re-established about 1947 on the site of one that had been exterminated in the 1930's. It expanded from 1.2 ha in 1947 to 108.7 ha in 1978 (Dalsted et al. 1981). The experimental site was in an area inhabited by prairie dogs for approximately 27 years (R. Klukas, pers. comm.). Buffalo grass (Buchloe dactyloides) was the dominant species, while other major grasses included western wheatgrass (Agropyron smithii), blue grama (Bouteloua gracllis) and tumblegrass (Schedonardus paniculatus). Important forbs included plains milkweed (Asclepias pumila), scar- 
let globemallow (Sphaeralcea coccinea), and various composite species. Fringed sagewort (Artemisia frigida) was the principal dwarf shrub (Brizuela 1987).

Data for bison utilization (R. Green, pers. commun.) of the experimental area were not available until July, 1985. In 1985, bison did not use the site in July, but did in August when approximately 40 animals used the area for $3 \mathrm{~d}$. In 1986, bison made frequent use of the study area: the mean herd size was 52 animals using the area an average of $4 \mathrm{~d}$ per month from May through August (Cid 1987).

Annual precipitation was $11 \%$ lower in 1985 and $27 \%$ higher in 1986 than the long-term average $(450 \mathrm{~mm})$ for WCNP. Moreover, the area experienced a severe drought until late July of 1985 . Not only was 1986 wetter, but also rainfall was more abundant early in the season, with over $40 \%$ of the total falling in June.

\section{Methods}

In December, 1984, 4 treatments were established: grazing by prairie dogs and bison (+PD+B), bison ${ }^{1}$ exclusion (+PD-B), prairie dog exclusion (-PD+B), and exclusion of both (-PD-B). The experimental design was a randomized block with 2 replicates, located approximately $40 \mathrm{~m}$ apart. In each block, two $50 \mathrm{~m} \times 50 \mathrm{~m}$ fenced ( $2 \mathrm{~m}$ high) exclosures were constructed (+PD-B and -PD$B)$, and 2 unfenced areas of the same size were delimited (+PD+B and $-P D+B)$. Park personnel removed prairie dogs from 1 of the exclosures (-PD-B) and from 1 of the adjacent unfenced areas $(-P D+B)$ of each replicate at the beginning of the study and, as necessary, throughout the experimental period. Sampling was conducted from May to September of 1985 and 1986.

In treatments with prairie dogs, their density was evaluated monthly as the mean of 3 counts, each of 2 minutes duration (Coppock 1981). Counting was done in the early morning and late afternoon when prairie dog activity was greatest.

Aboveground plant biomass was measured monthly. Plants were clipped in ten $0.25-\mathrm{m}^{2}$ circular frames randomly located in each treatment of each replicate. Plant biomass was separated into current year's biomass by growth form (graminoid, forb, and

${ }^{1}$ Although bison are the most abundant and well-documented ungulate grazers in the area, the exclosures effectively excluded all ungulates from the fenced areas. For simplicity, we refer to these areas as "bison exclusion".
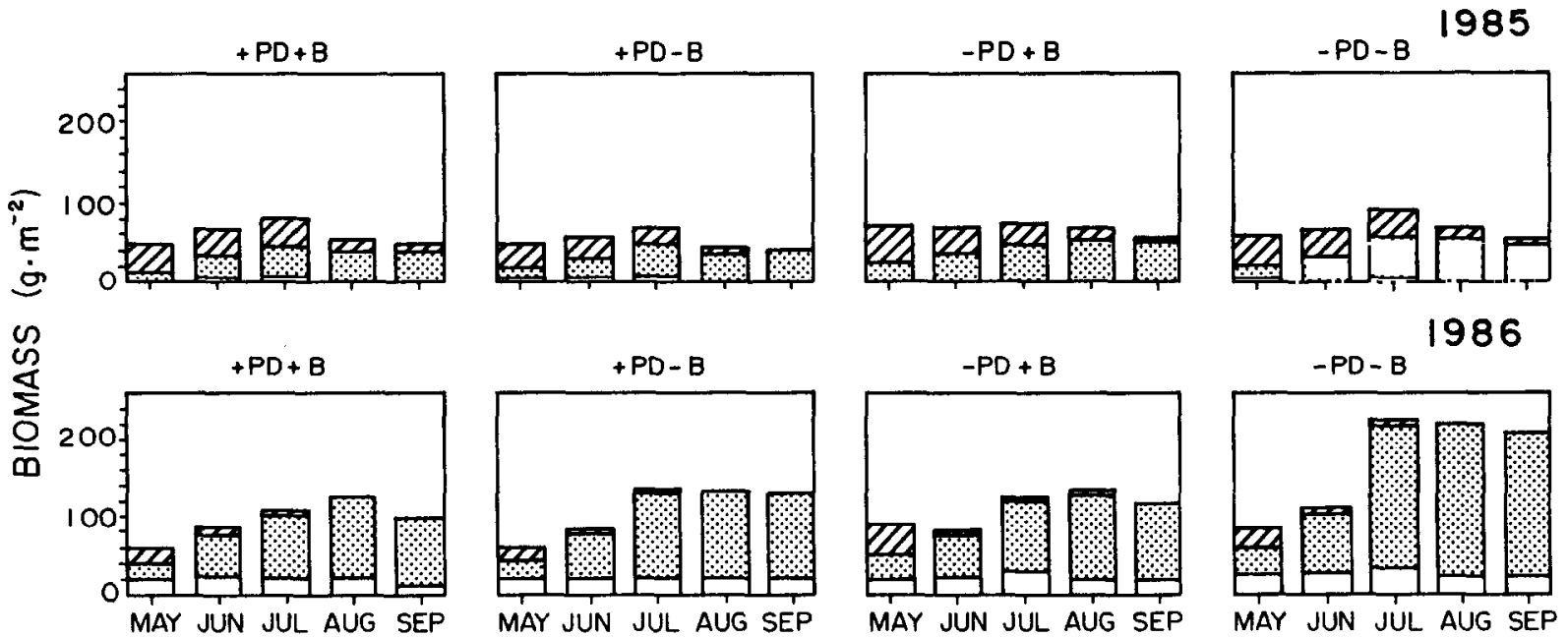

dwarf shrub) and previous year's standing dead biomass for all species combined. Samples were oven-dried at $60^{\circ} \mathrm{C}$ for $48 \mathrm{hr}$ and weighed. Canopy cover by species was estimated monthly in fifteen $0.1-\mathrm{m}^{2}(50 \times 20 \mathrm{~cm})$ frames (Daubenmire 1959) located at $10-\mathrm{m}$ intervals along 3 fixed transects $10 \mathrm{~m}$ apart from one another in each replicate. Plant species diversity $\left(\mathrm{H}^{\prime}\right.$, Shannon and Weaver 1963), equitability, and dominance concentration (C, Simpson 1949) were determined within each replicate from the cover data. Equitability (E) or evenness was expressed as the ratio of the observed diversity index to the maximum value of that index for the same number of species (Pielou 1975). Shoot nitrogen concentration (Kjeldahl method, AOAC 1965) was determined on graminoids and forbs collected monthly from 4 randomly selected plots in each replicate.

Data were statistically analyzed with a randomized block design ANOVA, split plot in time, with replicates (blocks), prairie dogs and bison as variables. Prairie dogs and bison were considered at 2 levels, present and absent. For statistical analysis, percentage contribution of graminoids, forbs, and dwarf shrubs to current year's standing crop, percent cover, and nitrogen concentration data were arcsin square-root transformed. However, data are presented with untransformed values. All differences reported are statistically significant at $p \leq 0.05$.

\section{Results}

There were no significant $(p>0.05)$ prairie dog $\times$ bison interactions for any of the plant characteristics measured in either 1985 or 1986. Consequently, only main effects of prairie dog and bison exclusion are reported in the ANOVA summary shown in Table 1.

Although prairie dog density was not significantly affected by the presence of bison in either year, it increased between 1985 and 1986 (Table 2). Averaged over the growing season, aboveground biomass was about twice as much in 1986 as in 1985 (Fig. 1). Peak aboveground biomass was reached in July-August each year, and graminoids were the dominant growth form in both years. In 1985, none of the variables had a significant effect on any measured biomass characteristic (Table 1, Fig. 2). In 1986, exclusion of prairie dogs and bison each significantly affected plant biomass, and the magnitude of their independent effects was similar. Specifically, averaged over the growing season, exclusion of

\footnotetext{
EZ PREVIOUS YEAR'S DEAD

CURRENT YEAR'S GRAMINOIDS

$\square$ CURRENT YEAR'S FORBS
}

Fig. 1. Monthly composition of aboveground biomass for 4 treatments: grazing by prairie dogs and bison (+PD+B); bison exclusion only (+PD-B); prairie dog exclusion only (-PD+B); and exclusion of both (-PD-B) in Wind Cave National Park during 1985 and 1986. Dwarf shrubs (not shown) accounted for $<2 \%$ of the total biomass in any treatment. 
Table 1. ANOVA results for the main effects of exclusion of prairie dogs (-PD) and bison (-B) on plant characteristics measured during the 1985 and 1986 growing seasons. No prairie dog $X$ bison interactions were significant $(p>0.05)$ either year. Symbols: $*=p \leq 0.05 ; \mathrm{NS}=$ not significant $(p>0.05)$.

\begin{tabular}{lcccc}
\hline \hline & \multicolumn{2}{c}{1985} & \multicolumn{2}{c}{1986} \\
Characteristic & $-P D$ & -B & -PD & -B \\
\hline Biomass (g/m²) & & & & \\
$\quad$ Previous year's dead & NS & NS & NS & NS \\
Current year's graminoid & NS & NS & $*$ & $*$ \\
Current year's forb & NS & NS & NS & NS \\
Current year's shrub & NS & NS & NS & NS \\
Current year's total & NS & NS & $*$ & $*$ \\
Total aboveground & NS & NS & $*$ & $*$ \\
Biomass (\% current year's total) & & & & \\
$\quad$ Graminoids & NS & NS & NS & $*$ \\
Forbs & NS & NS & $*$ & $*$ \\
Shrubs & NS & NS & NS & NS \\
Shoot N Concentration & & & & \\
Graminoids & $*$ & NS & NS & $*$ \\
Forbs & NS & NS & NS & NS \\
\hline
\end{tabular}

prairie dogs resulted in significant (Table 1 ) increases in aboveground total, current year's, and graminoid biomass of $36 \%, 36 \%$, and $43 \%$, respectively (Fig. 2). When bison were excluded, these same biomass measures increased $32 \%, 37 \%$, and $50 \%$, respectively. Moreover, because there were no significant $(p>0.05)$ prairie dog by bison interactions, the effects of excluding each herbivore species were independent and additive. That is, the biomass increase in the treatment from which both prairie dogs and bison were excluded (-PD-B) was not significantly different from the sum of the biomass increases resulting from exclusion of the 2 herbivores individually.

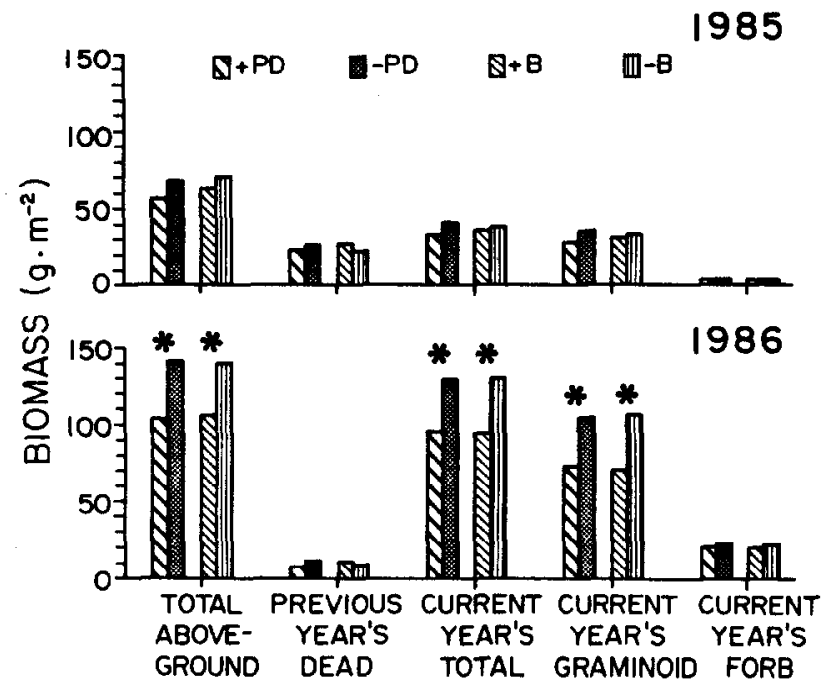

Fig. 2. Mean growing season biomass for treatments with $(+)$ and without (-) prairie dog (PD) and bison (B) grazing in Wind Cave National Park in 1985 and 1986. Mnin effects of treatments with and without a given herbivore are significantly different $(p<0.05)$ if marked with an astrisk $\left.{ }^{(}{ }^{\star}\right)$. There were no significant PD $\times$ B interaction terms in the ANOVA.

In response to grazer exclusion, the proportional contribution of different growth forms to total current year's biomass changed between years. For all treatments in 1985, 84-88\% of the total biomass was graminoids and $10-15 \%$ was forbs. In 1986 the proportion of forbs decreased significantly (Table 1) from 28 to $23 \%$ in treatments in which either prairie dogs or bison were excluded. Bison exclusion caused a slight, but significant, increase in the
Table 2. Seasonal average prairie dog density (no. ha-1 \pm 1 S.E.) and number of active burrows $\mathrm{ha}^{-1}$ at the beginning and end of the growing season in Research Reserve prairie dog colony, WCNP, with (+PD-B) and without (+PD+B) bison exclusion, during 1985-1986).

\begin{tabular}{|c|c|c|c|c|c|c|}
\hline & \multicolumn{2}{|c|}{$\begin{array}{l}\text { Prairie dog density } \\
\left.\text { (no. ha }{ }^{-1}\right)\end{array}$} & \multicolumn{4}{|c|}{$\begin{array}{l}\text { Active burrows } \\
\text { (no. ha }{ }^{-1} \text { ) }\end{array}$} \\
\hline & 1985 & 1986 & 1985 & & 1986 & \\
\hline $\begin{array}{l}+\mathrm{PD}+\mathrm{B} \\
+\mathrm{PD}-\mathrm{B}\end{array}$ & $\begin{array}{l}15.7 \pm 1.4 \mathrm{a} \\
19.5 \pm 1.6 \mathrm{a}\end{array}$ & $\begin{array}{l}27.1 \pm 1.8 b \\
28.4 \pm 1.8 b\end{array}$ & $\begin{array}{c}\text { May } \\
34 \\
28\end{array}$ & $\begin{array}{c}\text { Sep } \\
32 \\
26\end{array}$ & $\begin{array}{c}\text { May } \\
30 \\
30\end{array}$ & $\begin{array}{c}\text { Sep } \\
36 \\
37\end{array}$ \\
\hline
\end{tabular}

For each year or treatment, prairie dog densities with different letters differ significantly $(p<0.01)$.

proportion of graminoids (from 71 to $77 \%$ ); however, prairie dog exclusion had no significant effect. Dwarf shrubs were a minor component of the vegetation (less than $2 \%$ of the total biomass), and their proportion was not affected by treatment in either year.

In both years, species diversity, equitability, and dominance concentration were similar for all treatments (Table 3). However, species diversity and equitability were greater in 1986 than in 1985.

Over the growing season, mean shoot nitrogen concentration of graminoids decreased significantly from 1.49 to $1.38 \%$ in 1985 where prairie dogs were absent and from 1.64 to $1.50 \%$ in 1986 where bison were absent (Fig. 3, Table 1). Because there was no prairie dog by bison interaction on graminoid nitrogen concentration in either year, the decrease in seasonal nitrogen concentration was primarily a result of prairie dog exclusion in 1985 and bison exclusion in 1986 (Fig. 3). Effects of grazer exclusion were greatest in late summer 1985 and in late spring 1986 (Fig. 3). Shoot nitrogen concentration of forbs did not change significantly (Table 1) in response to grazing treatment in either year and, and across treatments, averaged $2.1 \%$ in 1985 and $1.8 \%$ in 1986 . The variability in forb nitrogen concentration among treatments and between years was high because of the patchy distributions of many uncommon species and their different phenologies.

\section{Discussion}

Only modest vegetational changes were observed in the 2 years following exclusion of bison and prairie dogs. The slow rate and small magnitude of the observed changes, particularly in 1985, might have been related to the amount and seasonal distribution of precipitation during the study. During the dry portion of the 1985 growing season, bison grazed principally in wetter areas of WCNP (R. Green, pers. commun.); therefore, treatments with and without bison were essentially the same until August when bison began utilizing the area. In 1986, when annual precipitation was above average, standing crop increased and bison used the study area intensively. Consequently, the difference between treatments with and without bison was greater in 1986 , and the magnitude of plant response to these treatments also was greater.

In 1986, the increased graminoid biomass but unchanged forb and shrub biomass in the grazing exclusion treatments was probably caused by selective herbivory. Because prairie dogs and bison prefer graminoids over other types of forage (Peden et al. 1974, Hansen and Gold 1977, Fagerstone et al. 1981, Popp 1981), it is not surprising that graminoid biomass accumulation increased when released from grazing pressure. Although aboveground net primary productivity (ANPP) can vary tremendously among years and sites at WCNP, it is relatively similar across a wide range of grazing intensities (Whicker and Detling 1988a). Similarly, Williamson et al. (1989) found that, depending upon weather patterns, ANPP of blue grama (an important grass at WNCP) remained constant or increased slightly with increasing grazing intensity on a shortgrass 
1985

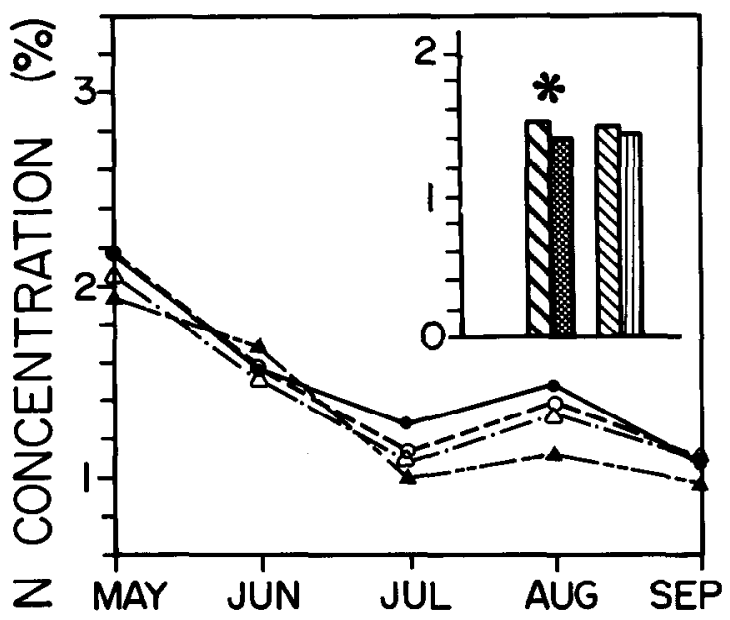

1986

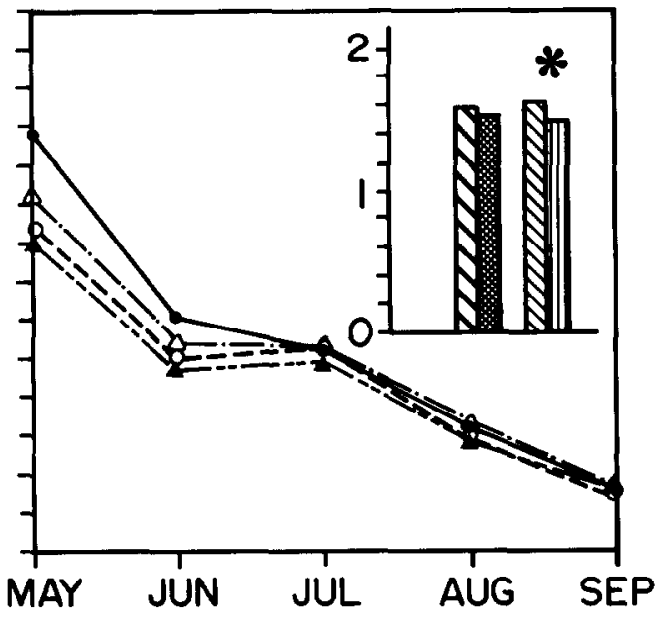

$\longrightarrow+P D+B \circ--0+P D-B \sim-\Delta-P D+B \rightarrow--\rightarrow-P D-B$

$\mathrm{Q}+\mathrm{PD} \quad \mathrm{Z}-\mathrm{PD} \quad \mathrm{B} \quad$ 四 $-\mathrm{B}$

Fis. 3. Seasonal changes in graminoid shoot nitrogen concentration and mean seasonal values (inset figures) for sites grazed by prairie dogs and bison, or with one or both herbivore species excluded. Symbols and statistics are as in Figures 1 and 2.

Table 3. Seasonal means within treatment for species diversity (H'), species number (N), equitability (E), and Simpson Index (C) for 4 treatments: graxing by prairie dogs and bison (+PD+B); bison exclusion only (+PD-B); prairie dog exclusion only (-PD+B); and exclusion of both (-PD-B) in Wind Cave National Park during 1985 and 1986.

\begin{tabular}{|c|c|c|c|c|c|c|c|c|}
\hline & \multicolumn{4}{|c|}{1985} & \multicolumn{4}{|c|}{1986} \\
\hline & $\mathbf{H}^{\prime}$ & $\mathbf{N}\left({ }^{*}\right)$ & E & C & $\mathbf{H}^{\prime}$ & $\mathbf{N}\left({ }^{*}\right)$ & $\mathbf{E}$ & C \\
\hline $\begin{array}{l}+P D+B \\
+P D-B \\
\text {-PD+B } \\
\text {-PD-B }\end{array}$ & $\begin{array}{l}1.35 \\
1.18 \\
1.33 \\
1.31\end{array}$ & $\begin{array}{l}11(6-4-0-1) \\
11(6-4-0-1) \\
12(6-5-0-1) \\
11(6-4-0-1)\end{array}$ & $\begin{array}{l}0.57 \\
0.50 \\
0.53 \\
0.55\end{array}$ & $\begin{array}{l}0.15 \\
0.21 \\
0.14 \\
0.21\end{array}$ & $\begin{array}{l}2.01 \\
1.96 \\
2.07 \\
1.77\end{array}$ & $\begin{array}{l}20(6-7-6-1) \\
20(6-7-6-1) \\
20(6-7-6-1) \\
17(6-6-5-0)\end{array}$ & $\begin{array}{l}0.67 \\
0.60 \\
0.69 \\
0.64\end{array}$ & $\begin{array}{l}0.13 \\
0.20 \\
0.15 \\
0.24\end{array}$ \\
\hline
\end{tabular}

(*-*_*-*) Indicates number of species of graminoids, perennial forbs, annual forbs, and dwarf shrubs, respectively.

steppe. Thus, the greater biomass accumulation in areas from which grazers had been excluded may have resulted more from reduced removal of the graminoid biomass than from an increase in its rate of production.

The temporal pattern of biomass accumulation in response to herbivore exclusion is somewhat comparable to other prairie dogbison/cattle exclusion experiments in mixed-grass prairies. In the growing season following individual and simultaneous elimination of ungulate and prairie dog grazing, Krueger (1986) found no differences in plant biomass between treatments. Even 4 years after prairie dog removal from a prairie dog-cattle grazed ranged, Uresk (1985) did not find increased production of grasses or forbs. In all of these studies, the intensity and duration of grazing by each species before removal no doubt affected the magnitude and timing of plant response.

As a consequence of the biomass responses, the relative proportion of graminoids increased and that of forbs decreased after exclusion of prairie dogs and bison. The reverse situation, increased forb:graminoid ratios following prairie dog colonization, has been observed in various grasslands (Koford 1958, Bonham and Lerwick 1976), including WCNP (Dalsted et al. 1981, Coppock et al. 1983a, Archer et al. 1987). Our study suggests that this effect of colonization may be reversed within 2 years of exclusion of prairie dogs or bison. In tall-grass prairie, abandonment of a prairie dog colony over a 10-year period resulted in fairly rapid secondary succession (Osborn and Allan 1949). The dominant species changed from forbs and annual grasses, to short grasses, and, finally, to midgrasses at the edge of the former colony. In shortgrass prairie, the number and cover of forbs actually increased and the grass cover decreased following several years of prairie dog abandonment (Klatt and Hein 1978). Grazing, in that case, had favored the maintenance of matforming grasses, blue grama and buffalo grass.

Plant species diversity may either increase or decrease in response to grazing, depending on initial conditions, intensity and duration of grazing impact, and how selective the grazers are for specific food items (Harper 1969). On short- and mixed-grass prairies, diversity is usually greater in prairie dog colonies than in nearby uncolonized sites (Bonham and Lerwick 1976, Archer et al. 1987, Coppock et al. 1983a, Collins and Barber 1985); however, Agnew et al. (1986) observed higher plant species richness in uncolonized mixed-grass prairie than in prairie dog colonies. In our study, 2 years of grazing exclusion did not produce large changes in plant species diversity. Mean seasonal diversity averaged over treatments increased in 1986, principally because of higher number of species, especially annual forbs (Table 2). This increase in species numbers was similar in all treatments and probably was related to the greater precipitation in 1986.

Many studies have demonstrated that grazing or defoliation increases shoot nitrogen concentration (Jameson 1964, Everson 1966, Chapin 1980, Detling and Painter (1983). Coppock et al. (1983a) found that plants in prairie dog colonies had higher shoot 
nitrogen concentrations than those of the same species in uncolonized sites. In another study, shoot nitrogen concentration of western wheatgrass plants was highest in areas grazed by prairie dogs and native ungulates, intermediate in areas excluded from grazing by prairie dogs or ungulates, and lowest in areas excluded from grazing by both (Krueger 1986). Our finding that graminoid shoot nitrogen concentration decreased when herbivores were removed is consistent with these observations. The seasonal pattern of graminoid shoot nitrogen concent ration suggests a strong relationship between this variable, grazing patterns, and precipitation. In particular, differences in shoot nitrogen concentration between treatments were greatest during that part of the growing season (Fig. 3) when the greatest amount of precipitation had occurred.

Lower shoot nitrogen concentrations following grazer êxclusion may result from a combination of causes. Grazing reduces average leaf age in the canopy, and younger leaves have lower $\mathrm{C}: \mathrm{N}$ ratios (Jameson 1964, Kamstra et al. 1968). In addition, defoliation may increase nitrogen uptake (Whicker and Detling 1988a) and allocation of nitrogen to leaves (Reuss et al. 1983, Jaramillo and Detling 1988, Polley and Detling 1988). Grazing may also reduce carbon translocation belowground (Detling 1988) and indirectly affect soil temperature (Archer and Detling 1986). Together or individually, these changes may increase net nitrogen mineralization rates (Stanford et al. 1973, Holland and Detling 1990). Moreover, fecal and urinary inputs to soil at frequently grazed sites may also increase nitrogen availability to plants (Davidson 1964, Floate 1981). Therefore, lower shoot nitrogen concentration in areas where prairie dogs or bison had been excluded also may reflect a lack of nitrogen inputs from their excretion products as well as decreased net nitrogen mineralization rates.

Our results indicated that continuous grazing by prairie dogs and intense, periodic grazing by bison and other native ungulates were of approximately equal importance in maintaining the vegetative characteristics of this prairie dog colony. While this and other studies have suggested that these changes are reversible, the rate of recovery probably depends to a large extent upon grassland type, initial plant species composition, grazing intensity, and weather conditions following the removal of herbivore pressure.

\section{Literature Cited}

Agnew, W., D.W. Uresk, and R.M. Hansen. 1986. Flora and fauna associated with prairie dog colonies and adjacent ungrazed mixed-grass prairie in western South Dakota. J. Range Manage. 39:135-139.

A.0.A.C. 1965. Official methods of analysis, 10th ed. Association of Official Agricultural Chemists, Washington, D.C.

Archer, S., and J.K. Detling. 1986. Evaluation of potential herbivore mediation of plant water status in a North American mixed-grass prairie. Oikos 47:287-291

Archer, S., M.G. Garrett, and J.K. Detling. 1987. Rates of vegetation change associated with prairie $\operatorname{dog}$ (Cynomys ludovicianus) grazing in North American mixed-grass prairie. Vegetatio 72:159-166.

Bonham, C.D., and A. Lerwick. 1976. Vegetation change induced by prairie dogs on shortgrass range. J. Range Manage. 29:221-225.

Brizuela, M.A. 1987. Prairie dog feeding behavior: response to colonization history and fire. Ph.D. Diss., Colorado State Univ., Fort Collins.

Chapin, III, F.S. 1980. Nutrient allocation and responses to defoliation in tundra plants. Arct. Alp. Res. 12:553-563.

Cid, M.S. 1987. Prairie dog and bison grazing effects on maintenance of attributes of a prairie dog colony. Ph.D. Diss., Colorado State Univ., Fort Collins.

Collins, S.L., and S.C. Barber. 1985. Effects of disturbance on diversity in mixed-grass prairie. Vegetatio 64:87-94.

Coppock, D.L. 1981. Impacts of black-tailed prairie dogs on vegetation in Wind Cave National Park. M.S. Thesis, Colorado State Univ., Fort Collins.

Coppock, D.L., J.K. Detling, J.E. Ellis, and M.I. Dyer. 1983a. Plantherbivore interactions in a North American mixed-grass prairie. I. Effects of black-tailed prairie dogs on intraseasonal aboveground plant biomass and nutrient dynamics and plant species diversity. Oecologia $56: 1-9$.
Coppock, D.L., J.E. Ellis, J.K. Detling, and M.I. Dyer. 1983b. Plantherbivore interactions in a North American mixed-grass prairie II. Responses of bisen to modification of vegetation by prairie dogs. Oecologia 56:10-15.

Dalsted, J., S. Sather-Blair, B.K. Worcester, and R. Klukas. 1981. Application of remote sensing to prairie dog management. J. Range Manage. 34:218-223.

Daubenmire, R. 1959. A canopy-coverage method of vegetation analysis. Northwest. Sci. 33:43-64.

Davidson, R.C. 1964. Theoretical aspects of nitrogen economy in grazing experiments. J. Brit. Grassl. Soc. 19:273-280.

Detling, J.K. 1988. Grassland and savannas: regulation of energy flow and nutrient cycling by herbivores. P 126-143. In: L.R. Pomeroy and J.J. Alberts (eds). Concepts of Ecosystem Ecology. Springer-Verlag. New York.

Detling, J.K., and E.L. Painter. 1983. Defoliation responses of western wheatgrass populations with diverse histories of prairie dog grazing. Oecologia 57:65-71.

Everson, A.C. 1966. Effects of frequent clipping at different stubble heights on western wheatgrass (Agropyron smithii Rydb.) Agron. 58:33-35.

Fagerstone, K.A., H.P. Tietjen, and O. Williams. 1981. Seasonal variation in the diet of black-tailed prairie dogs. J. Mamm. 62:820-824.

Floate, M.J.S. 1981. Effects of grazing by large herbivores on nitrogen cycling in agricultural ecosystems. P. 585-601. In: F.E. Clark and T. Rosswall (eds.) Terrestrial Nitrogen Cycles. Ecol. Bull 33. Royal Swedish Academy of Sciences, Stockholm.

Hansen, R.M., and I.K. Gold. 1977. Blacktail prairie dogs, desert cottontails and cattle tropic relations on shortgrass range. J. Range Manage. 30:210-214.

Harper, J.L. 1969. The role of predation in vegetation diversity. In: Diversity and stability in ecological systems. Brookhaven Symp. in Biology 22:48-62.

Holland, E.A., and J.K. Detling. 1990. Plant response to herbivory and belowground nitrogen cycling. Ecology 71:1040-1049.

Jameson, D.A. 1964. Effect of defoliation on forage plant physiology. In: Forage Plant Physiology and Soil Range Relationships. ASA Spec. Pub. 5, p. $67-80$.

Jaramillo, V.J., and J.K. Detling. 1988. Grazing history, defoliation, and competition: effects on shortgrass production and nitrogen accumulation. Ecology 69:1599-1608.

Kamstra, L.D., D.L. Schentzel, J.K. Lewis, and R.L. Elderkin. 1968. Maturity studies with western wheatgrass. J. Range Manage. 26:289-291.

King, J.A. 1955. Social behavior, social organization, and population dynamics in a black-tailed prairie dog town in the Black Hills of South Dakota. Contributions from the Laboratory of Vertebrate Biology No. 67. Univ. of Michigan, Ann Arbor.

Klatt, L.E., and D. Hein. 1978. Vegetative differences among active and abandoned towns of black-tailed prairie dogs (Cynomys ludovicianus). J. Range Manage. 31:315-317.

Knowles, C.J. 1986. Some relationships of black-tailed prairie dogs to livestock grazing. Great Basin Natur. 46:198-203.

Koford, C.B. 1958. Prairie dogs, whitefaces and blue grama. Wildl. Monogr. 3.

Krueger, K. 1986. Feeding relationships among bison, pronghorn, and prairie dogs: an experimental analysis. Ecology 67:760-770.

O'Meilia, M.E., F.L. Knopf, and J.C. Lewis. 1982. Some consequences of competition between prairie dogs and beef cattle. J. Range Manage. 35:580-585.

Osborn, B., and P.F. Allan. 1949. Vegetation of an abandoned prairie-dog town in a tall grass prairie. Ecology 30:322-332.

Peden, D.G., G.M. Van Dyne, R.W. Rice, and R.M. Hansen. 1974. The trophic ecology of Bison bison L. on shortgrass plains. J. Appl. Ecol. 11:489-498.

Pielou, E.C. 1975. Ecological diversity. John Wiley \& Sons, Inc.

Polley, H.W., and J.K. Detling. 1988. Herbivory tolerance of Agropyron smithii populations with different grazing histories. Oecologia 77:261-267.

Popp, J.K. 1981. Range ecology of bison on mixed grass prairie at Wind Cave National Park. M.S. Thesis, Iowa State Univ., Ames.

Reuss, R.W., S.J. McNaughton, and M.B. Coughenor. 1983. The effects of clipping, nitrogen source and nitrogen concentration on the growth responses and nitrogen uptake of an East African sedge. Oecologia $59: 253-261$

Shannon, C.E., and W. Weaver. 1963. The mathematical theory of communication. Urbana, Univ, of Illinois Press. 
Simpson, W.P. 1949. Measurement of diversity. Nature 106:414-418. Standford, G., M.H. Frerre, and D.H. Schwaninger. 1973. Temperature coefficient of soil nitrogen mineralization. Soil Sci. 115:321-323.

Uresk, D.W. 1985. Effects of controlling black-tailed prairie dogs on plant production. J. Range Manage. 38:466-468.

Whicker, A.D., and J.K. Detling. 1988a. Ecological consequences of prairie dog disturbances. BioScience 38:778-785.
Whicker, A.D., and J.K. Detling. 1988b. Modification of vegetation structure and ecosystem processes by North American grassland mammals. $P$. 301-316. In: M.J.A. Werger, H.J. During, and P.J.M. Van Der Aart, (eds.). Plant Form and Vegetation Structure. SPB Academic Publ. The Hague.

Williamson, S.C., J.K. Detling, J.L. Dodd, and M.I. Dyer. 1989. Experimental evaluation of the grazing optimization hypothesis. J. Range Manage. 42:149-152.

Wydeven, A.P., and R.B. Dahlgren. 1985. Ungulate habitat relationships in Wind Cave National Park. J. Wildl. Manage. 49:805-813. 